\title{
Cost of Debt and Corporate Profitability
}

\author{
Pierluigi Santosuosso ${ }^{1}$ \\ ${ }^{1}$ School of Economics, Sapienza University of Rome, Italy \\ Correspondence: Pierluigi Santosuosso, School of Economics, Sapienza University of Rome, Rome, Italy. Tel: \\ 39-6-4976-6460. E-mail: pierluigi.santosuosso@uniroma1.it
}

Received: December 13, 2013

Accepted: December 27, 2013

Online Published: January 23, 2014

doi: $10.5539 /$ ibr.v7n2p13

URL: http://dx.doi.org/10.5539/ibr.v7n2p13

\begin{abstract}
This paper examines the relationship between the cost of debt and corporate profitability using a sample of 3,556 Italian unlisted firms between 2007 and 2011. On the basis of the logistic regression model, we find that the cost of debt, measured by the interest expense to financial debt ratio, is negatively correlated to various proxies of firm profitability. These findings are consistent with previous research on the relevance of indirect costs of corporate distress. However, although the analysis found evidence that unprofitable firms are highly leveraged in accordance with the Pecking order theory, we also observed that the cost of debt for the firms included in the sample is inversely dependent on the amount of financial debt.
\end{abstract}

Keywords: cost of debt, profitability, corporate distress, pecking order theory, Italian firms

\section{Introduction}

The world economic crisis, characterized by a severe financing constraints such as the slowdown in bank lending and stock market volatility, has not diminished the need for analyzing capital structure related issues. Since 1958, when Modigliani and Miller suggested the irrelevance of financial policy, several studies have stressed that the cost of bankruptcy may offset the benefit arising from the tax deductibility of interest. In this debate, the direct and indirect costs of bankruptcy and corporate distress have been widely investigated in the research literature in order to assess the costs and benefits of debt financing. Although the estimation of these costs is far from exact, the relationship between bankruptcy and firm value is well-known; the expected default probability may increase the cost of debt and reduce the value of the firm (Warner, 1977; Altman, 1984; Van Horne \& Wachowicz, 2005; Almeida \& Philippon, 2007; Van Binsbergen, Graham, \& Yang, 2010, to name just a few).

The main purpose of this paper is to determine whether the cost of debt is affected by firm profitability. More specifically, we will examine the relationship between the cost of debt, measured by the interest expense to financial debt ratio, and various proxies of firm profitability using a sample of 3,556 Italian unlisted firms between 2007 and 2011. In the sample of firms, there are both firms that have an average net income $(75.5 \%$ of firms) and those which have a loss (24.5\%). We expected that the lower a firm's profitability, the higher the cost of debt due to the increased probability of corporate distress. As a result, the first hypothesis we attempt to verify is the existence of an inverse relationship between the cost of debt and firm profitability. This question is related to another central issue of corporate finance. According to the well-known Pecking order theory (POT), capital structure decisions lead to a negative correlation between profitability and leverage so that firms with low profitability have a degree of leverage greater than firms with high profitability. It is therefore likely that such a level of leverage might contribute to a further increase in the cost of debt because of the rising risk of distress that could derive from a high level of debt financing. Given this scenario, the second hypothesis we tested is whether the cost of debt is positively correlated to some proxies of firm leverage.

The hypotheses are analyzed on the basis of logistic regression. In the initial stage, different proxies of profitability are used as dependent variables, so that the firms are divided for each proxy into two groups according to their level of profitability. In the second stage, a similar division is made by taking the cost of debt as the dependent variable in order to have two groups of firms based on their level of debt cost, measured by the ratio of interest expenses to financial debt. The results of the regression analysis are partially consistent with the previous hypotheses. Our findings indicate a negative relationship between the cost of debt and profitability, suggesting the importance of the indirect cost of corporate distress. However, although the POT was confirmed, the analysis also found that the amount of financial debt is associated with a reduction in its cost. In particular, 
for our sample in which firms have primarily received financing from the banking system, the cost of debt is inversely related to the ratio of financial debt to total debt. This result does not differ from the Italian central bank's survey on the lending rate to the productive sector (Banca d'Italia, 2013).

The article is organized as follows: the second section provides a brief review of the literature; the third section describes the data, sample selection and methodology; the fourth section presents the results; the last section provides some concluding remarks.

\section{Literature Review}

For decades, corporate distress and bankruptcy have attracted a great deal of interest in the research literature. Since the seminal works of Beaver (Beaver, 1966; 1968) and Altman (Altman, 1968), a large volume of studies have analyzed the characteristics of firms in order to predict the state of crisis (for a literature review see Mansi, Maxwell, \& Zhang, 2012; Aziz \& Dar, 2006; Dimitras, Zanakis, \& Zopounidis, 1996; Guoquiang et al., 1999; Keasey \& Watson, 1991) and the resolution measures that can be taken to overcome financial and/or economic difficulties (for recent studies see Brown, Ciochetti, \& Riddiough, 2006; Hotchkiss et al., 2008; Annabi, Breton, \& François, 2012). Without going into a detailed examination of this vast subject, two main interrelated causes of corporate crisis emerge quite clearly. First, a corporate crisis can be affected by firm leverage. More specifically, a high degree of leverage might increase the risk of insolvency and consequently the cost of debt (Altman, 1984; Andrade \& Kaplan, 1998; Van Horne \& Wachowicz, 2005). Second, a drop in corporate profitability and/or a decline in other variables used as proxies of economic performances are generally interpreted as a sign of economic distress (John, Lang, \& Netter, 1992; Kang \& Shivdasani, 1997; Andrade \& Kaplan, 1998; Jiang \& Wang, 2009) and a possible cause of a corporate crisis.

Leverage and profitability do not seem to be independent of each other, especially for firms that are in serious economic and financial difficulties. Without covering this subject extensively, we underline the following two main causal connections.

First, the relationship between leverage and profitability is connected to the corporate financial policy. Although the issue of capital structure has been a controversial and disputed subject, a considerable number of empirical studies have confirmed the validity of the POT (Myers, 1984; Myers \& Majluf, 1984; Titman \& Wessels, 1988; Baskin, 1989; Allen, 1993; Fama \& French, 2002; Panno, 2003; Tong \& Green, 2005; Bharath, Pasquariello, \& Wu, 2009; Lemmon \& Zender, 2010; Al Manaseer et al., 2011; Mazen, 2012). According to the POT, firms with a high degree of leverage seem to be less profitable than firms with a lower degree of leverage. The negative correlation between leverage and profitability is due to the well-known preference order among the sources of funding. Firms prefer to finance new investments based on a specific hierarchical sequence; first, internal funds, then the issuing of debt and lastly the issuing of new shares (Myers, 1984; Myers \& Majluf, 1984). A method which is frequently used for testing the POT is based on the analysis of a firm's net debt issued to finance the "funds flow deficit", given by adding dividend payments, capital expenditure, the net increase in working capital, the current portion of long-term debt and by subtracting the operating cash flows after interest and taxes (Shyam-Sunder \& Myers, 1999). In addition to this method used by several studies (e.g., Chirinko \& Singha, 2000; Frank \& Goyal, 2003; Bauweraerts \& Colot, 2012), the POT has been tested on the basis of the relationship between profitability and firm's leverage (e.g., Titman \& Wessels, 1988; Baskin, 1989; Allen, 1993). The negative correlation between profitability and leverage is a factor that validates the theory since only profitable firms have the opportunity to finance new investments with retained earnings rather than through a new debt and/or equity issuance.

Second, the observed decline in economic performance and over-indebtedness could be connected by causal relationships that arise in the course of a firm's business activities. In addition to the existence of several general connections, a considerable number of empirical studies have specifically analysed how costly corporate distress and bankruptcy are. In particular, in case of bankruptcy, direct costs are related mainly to legal and accounting fees, the value of the managerial time spent (Warner, 1977) and other administrative costs (Altman, 1984). Indirect costs concern the loss of a substantial market share (Opler \& Titman, 1994), changes in operating performances, loss of suppliers, customers and managerial opportunities, a reduction in the ability of firms to obtain credit or issue securities (Altman, 1984), changes in trade receivables and debt policy (Molina \& Preve, 2009; George \& Hwang, 2010), decreasing investment opportunities (Chen \& Merville, 1999) and the lowering of other variables used as proxies of firm profitability (Tan, 2012). These undesirable effects contribute to an increase in the cost of debt and consequently may reduce firm's value (Andrade \& Kaplan, 1998; Weiss, 1990; Bris, Welh, \& Zhu, 2006). Although several studies have produced estimates of distress cost (Andrade \& Kaplan, 1998; Almeida \& Philippon, 2007; Van Binsbergen, Graham, \& Yang, 2010), its quantification continues to be 
debated in the research literature. The analysis of the cost of debt obviously becomes more complex when examining its relationship with various factors such as tax advantage (Miller, 1977; Graham, 2000; Green \& Hollifield, 2003), auditor fees (Dhaliwal et al., 2008), corporate ownership structure (Aslan \& Kumar, 2012), executive compensation (Kabir, Li, \& Veld-Merkoulova, 2013), firm internationalization (Reeb, Mansi, \& Allee, 2001), managerial ownership (Shuto \& Kitagawa, 2011) and human capital (Berk, Stanton, \& Zechner, 2010).

\section{Data and Methodology}

Our sample contains 3,556 Italian unlisted joint-stock companies between 2007 and 2011. In order to have a more homogeneous sample, we excluded banks, finance and insurance companies and firms which adopt the international accounting standards (IAS/IFRS). Firms which have to comply with international standards are primarily listed companies and other unlisted financial firms. Firms in the sample have a minimum of 35 million euro of annual revenues for at least one of the years under consideration. Regardless of the state of the firms' health, it was found that $75,5 \%$ of firms under investigation have an average net income over the time period 2007-2011, whereas the remaining firms have a loss. Table 1 shows other characteristics of the firms. Data on the sample firms were obtained from Aida (Bureau Van Dick, 2013).

Varying criteria have been chosen by researchers as proxies of profitability and leverage. As regards studies on the POT, examples of these proxies are: the operating income over sales, the operating income over total assets (Titnam \& Wessels, 1988) and the ratio of income before interest and taxes to invested capital (ROA) (Baskin, 1989) as proxies of profitability; long-term, short-term, and convertible debt divided by the market and book values of equity (Titnam \& Wessels, 1988) and debt to asset ratio defined as long-term liabilities plus short-term liabilities to assets, net of marketable securities (Allen, 1993) as proxies of leverage. Many other studies examined the relationship between profitability and leverage using different proxy variables (to name just a few: Fama \& French, 2002; Panno, 2003; Leary \& Roberts, 2005; Tong \& Green, 2005; Qureshi, 2009; Campbell, Hilscher, \& Szilagyi, 2010; Prime \& Qi, 2013) and similar proxies, such as Ebitda to assets or operating revenues to the financial cost of debt (Balcaen et al., 2012), are used in research in order to find a criterion for identifying economically distressed firms. In these studies, the variables were examined by highlighting changes over a specific time period (John, Lang, \& Netter, 1992; Jiang \& Wang, 2009) or emphasizing the difference between industry indicators (Kang \& Shivdasani, 1997; Lemmon, Ma, \& Tashjian, 2009).

Table 1. Descriptive statistics

\begin{tabular}{|c|c|c|c|c|c|}
\hline Variables & Mean & Median & St.Deviation & $1^{\text {th }}$ Quartile & $3^{\text {th }}$ Quartile \\
\hline Net income to assets & 0.020 & 0.015 & 0.058 & 0 & 0.041 \\
\hline Total debt to total assets & 0.633 & 0.659 & 0.197 & 0.504 & 0.784 \\
\hline Financial debt to total debt & 0.354 & 0.362 & 0.250 & 0.122 & 0.556 \\
\hline Bonds* & 0.0415 & 0 & 0.1411 & 0 & 0 \\
\hline Convertible bonds * & 0.0047 & 0 & 0.0426 & 0 & 0 \\
\hline Payables to banks * & 0.8183 & 0.9746 & 0.2901 & 0.7623 & 1 \\
\hline Payables to other fin. Institutions * & 0.0931 & 0 & 0.2258 & 0 & 0.0426 \\
\hline Shareholder loans * & 0.0424 & 0 & 0.1496 & 0 & 0 \\
\hline
\end{tabular}

Note: * Percentage of financial debt.

The present paper considers the following proxies of profitability: Return on sales, Return on investment (EBIT to the sum of total debt and equity), Return on assets (EBIT to total assets) and, in order to examine interest expenses, Ebitda to interest coverage ratio. For each of the selected average accounting ratios over the time period under examination, the present work has divided the sample firms into two main groups: "profitable firms" which are above the median and "unprofitable firms" that are below the median. In the second group, many firms have reported persistent losses. As pointed out earlier, the first quartile of the sample was entirely composed of firms which had losses over the time period 2007-2011.

In order to find a correlation between profitability, the cost of debt and leverage, this paper considers the binary dependent variable $\mathrm{Y}$ (profitable firms $\mathrm{Y}=1$; unprofitable firms $\mathrm{Y}=0$ ) and the following average accounting ratios for the period 2007-2011 $x_{p}$ as independent variables, using the logistic regression model: the cost of debt, 
measured by the interest expense to financial debt ratio, the ratio of financial debt to total debt and the ratio of total debt to total assets. More specifically, financial debt is composed of the debts shown in Table 1 (bonds, convertible bonds, payables to banks, payables to other financial Institutions and shareholder loans). Total debts include, in addition to financial debt items, the remaining debts: suppliers, payables to subsidiaries, payables to associated companies, taxes payable, payables to social security institutions and other payables. Let $p=P(Y=1)$, the logistic regression model is defined as:

$$
\operatorname{logit}(p)=\log (p /(1-p))=\beta_{0}+\beta_{1} x_{1}+\beta_{2} x_{2}+\ldots+\beta_{p} x_{p}
$$

where $\log (p /(1-p))$ is the natural logarithm of the odds, $p$ is the probability that the dependent variable occurs between 0 and $1, \beta_{p}$ is the $p$ th parameter of the logistic regression model obtained by the method of maximum likelihood, $x_{p}$ is the $p$ th explanatory or predictor variable.

Furthermore, this paper used the same methodology to analyze which predictor variables have an explanatory power on the cost of debt. As regards the average cost of debt over the period 2007-2011, we divided the sample firms into two groups: "firms with a high cost of debt" which are above the median and "firms with a low cost of debt" that are below the median. The correlation between the dependent variable Y ("firms with a high cost of debt" $\mathrm{Y}=1$; "firms with a low cost of debt" $\mathrm{Y}=0$ ) and the following ratios $x_{p}$ as independent variables was examined: Return on sales, Return on investment, Return on assets, Ebitda to interest coverage ratio, the ratio of financial debt to total debt and the ratio of total debt to total assets.

\section{Results}

Table 2 presents the findings of the logistic regression assuming various proxies of corporate profitability as dependent variables. This analysis did not find a significant difference in the cost of debt between firms with high profitability and firms with profitability below the median, except for a negative relationship between Ebitda to interest coverage ratio and the cost of debt. However, a strong correlation was found between profitability and leverage. In particular, the regression results indicate that the probability of having a "profitable firm" response $(\mathrm{Y}=1)$ increases as the values of the ratio of financial debt to total debt and the ratio of total debt to total assets decrease. This result corroborates the findings of a great deal of the previous work in this field. As shown by numerous researches (see for example Myers \& Majluf, 1984; Myers, 1984; Baskin, 1989; Titman \& Wessels, 1988; Allen, 1993; Fama \& French, 2002; Tong \& Green, 2005), the negative relationship between profitability and leverage validates the assumptions of the POT.

Further analysis was conducted by examining the correlation between the cost of debt as dependent variable and some accounting ratios as independent variables in order to examine some determinants of the cost of debt in relation to the profitability and indebtedness of firms. As described in section 3, the explanatory variables are the following: Return on sales, Return on investment, Return on assets, Ebitda to interest coverage ratio, the ratio of financial debt to total debt and the ratio of total debt to total assets. The results of the analysis, as shown in Table 3 , reveal two main findings.

First, the regression analysis suggests that the probability of having a "firm with a high cost of debt" increases as the profitability decreases, as explained by the negative correlation between the cost of debt and Return on investment, Return on assets and Ebitda to interest coverage ratio. The existence of a correlation between these variables supports the hypothesis that the cost of debt is affected by the corporate profitability. As pointed out in the section 2, the firm's inability to generate positive earnings is considered a sign of economic distress and consequently a factor that can increase the likelihood of a corporate crisis and the cost of debt financing.

Second, the logistic regression indicates that there was a highly significant negative correlation between the cost of debt and the ratio of financial debt to total debt. The inverse relationship between these variables is consistent with the periodic surveys of the Italian central bank (Banca d'Italia, 2013). For example, for term loans from 1 to 5 years, the lending rate to the productive sector ranged from $5.26 \%$ (for loans up to $€ 250,000$ ) to $2.83 \%$ (for loans of more than $€ 25,000,000$ ). Although the identification of the causes of this relationship is beyond the purpose of the present study, we mention some possible interpretations, as for example, the relationship can be connected to some characteristics of firms (e.g. size, level of risk, ownership structure, industries in which the firm operates), the types of loans and the bank's credit policies. 
Table 2. Profitability and logistic regression results

\begin{tabular}{|c|c|c|c|c|c|}
\hline Ros & Estimate & Std Error & $\mathrm{z}$ value & $\operatorname{Pr}(>|z|)$ & \\
\hline Const & 2.20952 & 0.13309 & 16.60230 & $<0.00001$ & \\
\hline Cost of debt & 0.00000 & 0.00001 & 0.85680 & 0.39154 & \\
\hline Financial debt to total debt & -0.09374 & 0.14514 & -0.64590 & 0.51836 & \\
\hline Total debt to total assets & -3.41800 & 0.20026 & -17.06820 & $<0.00001$ & $* * *$ \\
\hline Roi & Estimate & Std Error & $\mathrm{z}$ value & $\operatorname{Pr}(>|z|)$ & \\
\hline Const & 1.26284 & 0.12706 & 9.93880 & $<0.00001$ & \\
\hline Cost of debt & 0.00000 & 0.00001 & 0.45300 & 0.65054 & \\
\hline Financial debt to total debt & -3.33494 & 0.15972 & -20.87930 & $<0.00001$ & $* * *$ \\
\hline Total debt to total assets & -0.13381 & 0.19066 & -0.70180 & 0.48279 & \\
\hline Roa & Estimate & Std Error & $z$ value & $\operatorname{Pr}(>|z|)$ & \\
\hline Const & 1.98860 & 0.13012 & 15.28260 & $<0.00001$ & \\
\hline Cost of debt & 0.00000 & 0.00001 & 0.67010 & 0.50279 & \\
\hline Financial debt to total debt & -0.87170 & 0.14398 & -6.05440 & $<0.00001$ & $* * *$ \\
\hline Total debt to total assets & -2.63733 & 0.19278 & -13.68060 & $<0.00001$ & $* * *$ \\
\hline Ebitda to Interest & Estimate & Std Error & $\mathrm{z}$ value & $\operatorname{Pr}(>|z|)$ & \\
\hline Const & 5.296510 & 0.202404 & 26.168000 & $<0.00001$ & \\
\hline Cost of debt & -0.000029 & 0.000014 & -2.072100 & 0.03826 & $* *$ \\
\hline Financial debt to total debt & -4.135280 & 0.187012 & -22.112300 & $<0.00001$ & $* * *$ \\
\hline Total debt to total assets & -5.890130 & 0.263633 & -22.342200 & $<0.00001$ & $* * *$ \\
\hline
\end{tabular}

Notes: *** Significant at the 0.01 level, ** Significant at the 0.05 level, ${ }^{*}$ Significant at the 0.10 level (two-tailed).

Table 3. Cost of debt and logistic regression results

\begin{tabular}{|c|c|c|c|c|c|}
\hline Cost of Debt & Estimate & Std Error & $\mathrm{z}$ value & $\operatorname{Pr}(>|z|)$ & \\
\hline Const & 0.9335130 & 0.1405560 & 6.6416000 & $<0.00001$ & \\
\hline Ros & 0.0019835 & 0.0020071 & 0.9883000 & 0.32303 & \\
\hline Roi & -0.1539540 & 0.0845230 & -1.8214000 & 0.06854 & $*$ \\
\hline Roa & -1.3745200 & 0.5897190 & -2.3308000 & 0.01976 & $* *$ \\
\hline Ebitda to interest & -0.0000036 & 0.0000017 & -2.1417000 & 0.03222 & $* *$ \\
\hline Financial debt to total debt & -2.4318100 & 0.1531700 & -15.8765000 & $<0.00001$ & $* * *$ \\
\hline Total debt to total assets & 0.0378257 & 0.1930400 & 0.1959000 & 0.84465 & \\
\hline
\end{tabular}

Notes: *** Significant at the 0.01 level, ** Significant at the 0.05 level, ${ }^{*}$ Significant at the 0.10 level (two-tailed).

\section{Summary and Concluding Remarks}

This paper aims to verify the existence of a relationship between the cost of debt and corporate profitability in order to assess the importance of the indirect costs of corporate distress. A low level of profitability, and $a$ fortiori the existence of losses, should be associated with the risk of corporate distress and therefore with an increase in the cost of debt. In addition, the negative correlation between the cost of debt and profitability could be aggravated by the corporate financial policy. According to the POT, unprofitable firms often have a high degree of leverage since only profitable firms have the opportunity to finance new investments with retained earnings rather than with a debt and/or equity issuance. Consequently, the second relationships we analyzed is whether the cost of debt is correlated to various proxies of firm leverage.

The sample under examination was made up of 3,556 Italian unlisted firms between 2007 and 2011. We 
excluded banks, finance and insurance companies and firms which adopt the international accounting standards (IAS/IFRS). The sample of firms has a strong relationship with the banking system; payables to banks and to other financial institutions represent on average more than $90 \%$ of these financial debt.

On the basis of logistic regression, the findings of this study show that: the probability of having a "firm with a high cost of debt" increases as corporate profitability decreases; the probability of having a "profitable firm" increases as leverage decreases. These results confirm the main question posed in this study about the relationship between the cost of debt and profitability. Furthermore, another interesting correlation emerged between the cost of debt and the ratio of financial debt to the total debt. The negative correlation between the two variables reveals the amount of financial debt as a determinant of interest expense. For our sample, in which firms have a strong relationship with the banking system and a very limited presence of public debt, the cost of financial debt decreases as its amount divided by the total debt increases.

The results of this paper have some important implications. This work contributes to the existing knowledge of the indirect cost of corporate distress by providing additional evidence as regards the relationship between the cost of financial debt, profitability and financial debt. This information allows lenders and equity investors to improve their decision-making process in order to protect the value of their investments and enables firms to optimize their choices about capital structure. This study has, however, some limitations. Apart from the fact that the research is restricted to Italian companies, the paper did not investigate the reasons for the relationship between the cost of financial debt and its amount since their identification would require at least an analysis of the characteristics of the individual components of financial debt and a comparison between firms which have a strong relationship with the banking system and firms with easy access to the bond and equity market. Future research may investigate these issues and their causal connections by introducing other factors that may influence the relationship between profitability and the cost of debt, such as the industries in which firms operate, their status (listed or non-listed), the level of interest rates and the availability of debt capital.

\section{References}

Al Manaseer, M. F., Gonis, E., Al-Hindawi, R. M., \& Sartawi, I. I. (2011). Testing the Pecking Order and the Target Models of capital structure: evidence from UK. European Journal of Economics, Finance and Administrative Sciences, 41, 84-96.

Allen, D. E. (1993). The pecking order hypothesis: Australian evidence. Applied Financial Economics, 3(2), 101-112. http://dx.doi.org/10.1080/758532828

Almeida, H., \& Philippon, T. (2007). The Risk-Adjusted Cost of Financial Distress. The Journal of Finance, 62(6), 2557-2586. http://dx.doi.org/10.1111/j.1540-6261.2007.01286.x

Altman, E. I. (1968). Financial ratios, discriminant analysis and the prediction of corporate bankruptcy. Journal of Finance, 23(4), 589-609. http://dx.doi.org/10.1111/j.1540-6261.1968.tb00843.x

Altman, E. I. (1984). A further empirical investigation of the bankruptcy cost question. Journal of Finance, 39(4), 1067-1089. http://dx.doi.org/10.1111/j.1540-6261.1984.tb03893.x

Andrade, G., \& Kaplan, S. N. (1998). How costly is financial (not economic) distress? Evidence from highly leveraged transactions that became distressed. Journal of Finance, 53(5), $1443-1493$. http://dx.doi.org/10.1111/0022-1082.00062

Annabi, A., Breton, M., \& François, P. (2012). Resolution of financial distress under Chapter 11. Journal of Economic Dynamics \& Control, 36(12), 1867-1887. http://dx.doi.org/10.1016/j.jedc.2012.06.004

Aslan, H., \& Kumar, P. (2012). Strategic ownership structure and the cost of debt. The Review of Financial Studies, 25(7), 2257-2299. http://dx.doi.org/doi:10.1093/rfs/hhs062

Aziz, M. A., \& Dar, H. A. (2006). Predicting corporate bankruptcy: where we stand? Corporate Governance, 6(1), 18-33. http://dx.doi.org/doi 10.1108/14720700610649436

Balcaen, S., Manigart, S., Buyze, J., \& Ooghe, H. (2012). Firm exit after distress: differentiating between bankruptcy, voluntary liquidation and M \& A. Small Business Economics, 39(4), 949-975. http://dx.doi.org/10.1007/s11187-011-9342-7

Banca d'Italia. (2013). Statistical Bulletin, n.2. Roma, Italia: Banca d'Italia.

Baskin, J. (1989). An Empirical Investigation of the Pecking Order Hypothesis. Financial Management, 18(1), 26-35. http://dx.doi.org/10.2307/3665695

Bauweraerts, J., \& Colot, O. (2012). Pecking-Order or static trade-off theory in family firms? Evidence from 
Belgium. International Business Research, 5(11), 1-11. http://dx.doi.org/10.5539/ibr.v5n11p1

Beaver, W. H. (1966). Financial Ratios as Predictors of Failure. Journal of Accounting Research, Supplement, 4(3), 71-111. http://dx.doi.org/10.2307/2490171

Beaver, W. H. (1968). Market Prices, Financial Ratios, and the Prediction of Failure. Journal of Accounting Research, 6(2), 179-192. http://dx.doi.org/10.2307/2490233

Berk, J. B, Stanton, R., \& Zechner, J. (2010). Human Capital, Bankruptcy, and Capital Structure. The Journal of Finance, 65(3), 337-347. http://dx.doi.org/10.1111/j.1540-6261.2010.01556.x

Bharat, S. T., Pasquariello, P., \& Wu, G. (2009). Does asymmetric information drive capital structure decisions? The Review of Financial Studies, 22(8), 3211-3243. http://dx.doi.org/10.1093/rfs/hhn076

Bris, A., Welch, I., \& Zhu, N. (2006). The Costs of bankruptcy: chapter 7 liquidation versus Chapter 11 reorganization. The Journal of Finance, 61(3), 1253-1303. http://dx.doi.org/10.1111/j.1540-6261.2006.00871.x

Brown, D. T., Ciochetti, B. A., \& Riddiough, T. J. (2006). Theory and evidence on the resolution of financial distress. The Review of Financial Studies, 19(4), 1357-1397. http://dx.doi.org/10.1093/rfs/hhj031

Bureau Van Dijk. (2013). Retrieved July 20, 2013, from https://aida.bvdinfo.com

Campbell, J. Y., Hilscher, J., \& Szilagyi, J. (2010). Predicting financial distress and the performance of distressed stocks. Retrieved from http://kuznets.fas.harvard.edu/ campbell/papers/..._JOIM.pdf

Chen, G. M., \& Merville, L. J. (1999). An analysis of the underreported magnitude of the total indirect costs of financial distress. Review of Quantitative Finance and Accounting, 13, 277-293. http://dx.doi.org/10.1023/A:1008370531669

Chirinko, R. S., \& Singha, A. R. (2000). Testing static trade-off against pecking order models of capital structure: a critical comment. Journal of Financial Economics, 58, 417-425. http://dx.doi.org/10.1016/S0304-405X(00)00078-7

Dhaliwal, D. S., Gleason, C. A., Heitzman, S., \& Melendrez, K. D. (2008). Auditor Fees and Cost of Debt. Journal of Accounting, Auditing \& Finance, 23(1), 1-22.

Dimitras, A. I., Zanakis, S. H., \& Zopounidis, C. (1996). A survey of business failures with an emphasis on prediction methods and industrial applications. European Journal of Operational Research, 90(3), 487-513. http://dx.doi.org/10.1016/0377-2217(95)00070-4

Fama, E. F., \& French, K. R. (2002). Testing trade-off and pecking order predictions about dividends and debt. The Review of Financial Studies, 15(1), 1-33. http://dx.doi.org/10.1093/rfs/15.1.1

Frank, M. Z., \& Goyal, V. K. (2003). Testing the pecking order theory of capital structure. Journal of Financial Economics, 67, 217-248. http://dx.doi.org/10.1016/S0304-405X(02)00252-0

George, T. J., \& Hwang, C-Y. (2010). A resolution of the distress risk and leverage puzzles in the cross section of stock returns. Journal of Financial Economics, 96, 56-79. http://dx.doi.org/10.1016/j.jfineco.2009.11.003

Graham, J. R. (2000). How big are the tax benefits of debt? The Journal of Finance, 55(5), 1901-1941. http://dx.doi.org/10.1111/0022-1082.00277

Green, R. C., \& Hollifield, B. (2003). The personal-tax advantages of equity. Journal of Financial Economics, 67, 175-216. http://dx.doi.org/10.1016/S0304-405X(02)00246-5

Guoqiang, Z., Hu, M. Y., Patuwo, B. E., \& Indro, D. C. (1999). Artificial neural networks in bankruptcy prediction: general framework and cross-validation analysis. European Journal of Operational Research, 116, 16-32. http://dx.doi.org/10.1016/S0377-2217(98)00051-4

Hotchkiss, E. S., John, K., Mooradian, R. M., \& Thorburnk, K. S. (2008). Bankruptcy and the resolution of financial distress. In B. Espen Eckbo (Ed.), Handbook of Empirical Corporate Finance (Vol. 2). Elsevier B.V. Retrieved from http://mba.tuck.dartmouth.edu/.../Ch14-N53090.pdf

Jiang, K., \& Wang, S. (2009). Firms in economic distress: survival strategies and economic factors (pp. 1-40). Retrieved from http://ssrn.com/abstract $=1465181$

John, R., Lang, L. H. P., \& Netter, J. (1992). The voluntary restructuring of large firms in response to performance decline. The Journal of Finance, 47(3), 891-917. http://dx.doi.org/10.1111/j.1540-6261.1992.tb03999.x 
Kabir, R., Li, H., \& Veld-Merkoulova, Y. V. (2013). Executive compensation and the cost of debt. Journal of Banking \& Finance, 3, 2893-2907. http://dx.doi.org/10.1016/j.jbankfin.2013.04.020

Kang, J, K., \& Shivdasani, A. (1997). Corporate restructuring during performance declines in Japan. Journal of Financial Economics, 46, 29-65. http://dx.doi.org/10.1016/S0304-405X(97)00024-X

Keasey, K., \& Watson, R. (1991). Financial distress prediction models: a review of their usefulness. British Journal of Management, 2, 89-102. http://dx.doi.org/10.1111/j.1467-8551.1991.tb00019.x

Leary, M. T., \& Roberts, M. R. (2005). Do firms rebalance their capital structures? Journal of Finance, 60(6), 2575-2619. http://dx.doi.org/10.1111/j.1540-6261.2005.00811.x

Lemmon, M. L., \& Zender, J. F. (2010). Debt capacity and tests of capital structure theories. Journal of Financial and Quantitative Analysis, 45(5), 1161-1187. http://dx.doi.org/10.1017/S0022109010000499

Lemmon, M., Ma, Y. Y., \& Tashjian, E. (2009). Survival of the fittest? Financial and economic distress and restructuring outcomes in Chapter 11. Retrieved from http://ssrn.com/abstract=1325562

Mansi, S. A., Maxwell, W. F., \& Zhang, A. J. (2012). Bankruptcy prediction models and the cost of debt. Journal of Fixed Income, 21(4), 25-42. http://dx.doi.org/10.3905/jfi.2012.21.4.025

Mazen, G. (2012). French firm's financing choices: towards a reconciliation of the static trade-off theory and the Pecking Order Theory? International Journal of Financial Research, 3(1), 57-72. http://dx.doi.org/10.5430/ijfr.v3n1p57

Miller, M. H. (1977). Debt and taxes. The Journal of Finance, 32(2), 261-275.

Molina, C. A., \& Preve, L. A. (2009). Trade receivables policy of distressed firms and its effect on the costs of financial distress. Financial Management, 38(3), 663-686. http://dx.doi.org/10.1111/j.1755-053X.2009.01051.x

Myers, S. C. (1984). The capital structure puzzle. Journal of Finance, 39, 575-592. http://dx.doi.org/10.2307/2327916

Myers, S. C., \& Majluf, N. (1984). Corporate financing and investment decisions when firms have information that investors do not have. Journal of Financial Economics, 13(2), 187-221. http://dx.doi.org/10.1016/0304-405X(84)90023-0

Opler, T. C., \& Titman, S. (1994). Financial distress and corporate performance. The Journal of Finance, 49(3), 1015-1040. http://dx.doi.org/10.1111/j.1540-6261.1994.tb00086.x

Panno, A. (2003). An empirical investigation on the determinants of capital structure: the UK and Italian experience. Applied Financial Economics, 13, 97-112. http://dx.doi.org/10.1080/09603100210100882

Prime, P. B., \& Qi, L. (2013). Determinants of firm leverage: evidence from China. The Chinese Economy, 46(2), 74-106. http://dx.doi.org/10.2753/CES1097-1475460204

Qureshi, M. A. (2009). Does pecking order theory explain leverage behavior in Pakistan? Applied Financial Economics, 19, 1365-1370. http://dx.doi.org/10.1080/09603100902817592

Reeb, D. M., Mansi, S. A., \& Allee, J. M. (2001). Firm internationalization and the cost of debt financing: evidence from non-provisional publicly traded debt. Journal of Financial and Quantitative Analysis, 36(3), 395-414. http://dx.doi.org/10.2307/2676289

Shuto, A., \& Kitagawa, N. (2011). The effect of managerial ownership on the cost of debt: evidence from Japan. Journal of Accounting, Auditing \& Finance, 26(3), 590-620. http://dx.doi.org/10.1177/0148558X11401553

Shyam-Sunder, L., \& Myers, S. C. (1999). Testing static tradeoff against pecking order models of capital $\begin{array}{lllll}\text { Structure. Journal of } & \text { Financial }\end{array}$ http://dx.doi.org/10.1016/S0304-405X(98)00051-8

Tan, T. K. (2012). Financial distress and firm performance: evidence from the Asian financial crisis. Journal of Finance and Accountancy, 11, 36-45.

Titman, S., \& Wessels, R. (1988). The determinants of capital structure choice. Journal of Finance, 43(1), 1-19. http://dx.doi.org/10.1111/j.1540-6261.1988.tb02585.x

Tong, G., \& Green, C. J. (2005). Pecking order or trade-off hypothesis? Evidence on the capital structure of $\begin{array}{lllll}\text { Chinese } & \text { companies. } & \text { Applied } & \text { Economics, } & \text { 37(19), }\end{array}$ http://dx.doi.org/10.1080/00036840500319873 
Van Binsbergen, J. H., Graham, J. R., \& Yang, J. (2010). The Cost of Debt. The Journal of Finance, 65(6), 2089-2136. http://dx.doi.org/10.1111/j.1540-6261.2010.01611.x

Van Horne, J. C., \& Wachowicz Jr, J. M. (2005). Fundamentals of financial management. Edinburgh Gate, Harlow, Essex, UK: Pearson Education Limited.

Warner, J. B. (1977). Bankruptcy costs: some evidence. The Journal of Finance, 32(2), $337-347$. http://dx.doi.org/10.2307/2326766

Weiss, L. A. (1990). Bankruptcy resolution: Direct costs and violation of priority of claims. Journal of Financial Economics, 27, 285-314. http://dx.doi.org/10.1016/0304-405X(90)90058-8

\section{Copyrights}

Copyright for this article is retained by the author(s), with first publication rights granted to the journal.

This is an open-access article distributed under the terms and conditions of the Creative Commons Attribution license (http://creativecommons.org/licenses/by/3.0/). 